\begin{tabular}{|l|l|l||}
\hline \multicolumn{2}{|c|}{ PublisherInfo } \\
\hline \hline PublisherName & $:$ & BioMed Central \\
\hline \hline PublisherLocation & $:$ & London \\
\hline \hline PublisherImprintName & $:$ & BioMed Central \\
\hline \hline
\end{tabular}

\title{
A novel MyD88 homolog that is essential for LPS signalling
}

\begin{tabular}{|l|l|l||}
\hline \multicolumn{2}{|c|}{ ArticleInfo } \\
\hline \hline ArticleID & $:$ & 47 \\
\hline \hline ArticleDOI & $:$ & $10.1186 /$ ar-2001-72350 \\
\hline \hline ArticleCitationID & $:$ & 72350 \\
\hline \hline ArticleSequenceNumber & $:$ & 4 \\
\hline \hline ArticleCategory & $:$ & Paper Report \\
\hline \hline ArticleFirstPage & $:$ & 1 \\
\hline \hline ArticleLastPage & $:$ & 4 \\
\hline \hline & & RegistrationDate $: 2001-11-1$ \\
& $:$ & Received \\
ArticleHistory & $:$ & Accepted 2001-11-1 \\
& $:$ 2001-11-16 \\
\hline \hline ArticleCopyright & $:$ & Biomed Central Ltd2001 \\
\hline \hline ArticleGrants & $:$ & \\
\hline \hline
\end{tabular}




\begin{tabular}{|l|l|l||}
\hline ArticleContext & $:$ & 130753311 \\
\hline
\end{tabular}

$\underline{\text { Evangelos Andreakos, }}{ }^{\text {Aff1 }}$

Aff1 Kennedy Institute of Rheumatology, London, UK

\section{Keywords}

LPS, Mal, MyD88, Toll-like receptor

\section{Context}

Toll-like receptors (TLRs) play an essential role in innate and acquired immune responses. They recognize a wide range of exogenous and endogenous ligands with remarkable specificity. TLR4, in particular, is involved in the recognition of bacterial lipopolysaccharide (LPS) and fibronectin fragments. TLRs owe their name to a highly homologous cytoplasmic domain, the Toll-IL-1 receptor (TIR) domain, that they share with the Drosophila Toll receptor and the IL-1 receptor (IL-1R) family members; this led to the suggestion that TLR/IL-1R family members use an analogous framework of signalling molecules. Upon ligand binding TLRs recruit the adaptor molecule MyD88 through homotypic interactions with a Toll domain found in the $\mathrm{C}$ terminus of MyD88. MyD88, in turn, recruits IL-1-receptor-associated kinase (IRAK) and IRAK-2, which induce the activation of MAPK and NF-?B through TNF-receptor-associated factor (TRAF)6. A long-standing problem with this model, however, was the observation that LPS can still induce MAPK and NF-?B activation in peritoneal macrophages from MyD88- and IRAK- but not TRAF6-deficient mice, whereas IL-1 and IL-18 cannot. This was a paradox and suggested that LPS may use, in addition to MyD88/IRAK, an as yet unidentified mediator to activate NF-?B through TRAF6 and MAPKs.

\section{Significant findings}

This study reports the existence of a MyD88 homolog termed MyD88-adapter-like (Mal) or TIRAP, also identified independently by Horng et al (see Additional information). Mal contains a TIR domain at its $\mathrm{C}$ terminus but, unlike MyD88, it lacks a death domain at its $\mathrm{N}$ terminus. Mal associates specifically with TLR4 but not other TLRs. An inhibitory form of Mal can prevent LPS- (but not IL-1- or TNF-a-) induced NF-?B activation in RAW and THP-1 cells. 


\section{Comments}

This study provides the missing link between TLR4 ligand binding and activation of MAPK and NF?B. It demonstrates that TLR4 recruits Mal, which specifically associates with IRAK-2 to activate downstream signalling in response to LPS. These results explain the paradoxical observations in MyD88- and IRAK-deficient mice; however, the paper raises more questions than it answers. How is Mal selectively localized to TLR4 and not to other TLRs? What confers this specificity? Is Mal required for signalling through other TLRs and TLR combinations, or other additional TLR ligands? And finally, how does Mal activate downstream signalling pathways if IRAK-2 does not possess kinase activity? More importantly, does Mal have a role in chronic inflammatory disease states, and can it be a therapeutic target? Future experiments will be aimed at answering these questions.

\section{Methods}

Northern blotting, RT-PCR, DNA transfection assays, luciferase reporter assays, western blotting, immunoprecipitation, yeast two-hybrid analysis

\section{Additional information}

Adachi O, Kawai T, Takeda K, Matsumoto M, Tsutsui H, Sakagami M, Nakanishi K, Akira S: Targeted disruption of the MyD88 gene results in loss of IL-1- and IL-18-mediated function.

Immunity 1998, 9:143-150 (PubMed abstract).

Kawai T, Adachi O, Ogawa T, Takeda K, Akira S: Unresponsiveness of MyD88-deficient mice to endotoxin.

Immunity 1999, 11:115-122 (PubMed abstract).

Horng T, Barton GM and Medzhitov R: TIRAP: an adapter molecule in the Toll signaling pathway.

Nat Immunol 2001, 2:835-841 (PubMed abstract). 


\section{References}

1. Fitzgerald KA, Palsson-McDermott EM, Bowie AG, Jefferies CA, Mansell AS, Brady G, Brint E, Dunne A, Gray P, Harte MT, McMurray D, Smith DE, Sims JE, Bird TA, O'Neill LA: Mal

(MyD88-adapter-like) is required for Toll-like receptor-4 signal transduction. Nature. 2001, 413: 78-83.

This PDF file was created after publication. 